九州大学学術情報リポジトリ

Kyushu University Institutional Repository

\title{
Biomass Production of Indonesian Indigenous Leptolyngbya Strain on NPK Fertilizer Medium and its Potential as a Source of Biofuel
}

Nining Betawati Prihantini

Department of Biology, Faculty of Mathematics and Natural Sciences, Universitas Indonesia

Rakhmayanti, Nurul

Department of Biology, Faculty of Mathematics and Natural Sciences, Universitas Indonesia

Handayani, Sri

Department of Chemistry, Faculty of Mathematics and Natural Sciences, Universitas Indonesia

Sjamsuridzal, Wellyzar

Department of Biology, Faculty of Mathematics and Natural Sciences, Universitas Indonesia

他

https://doi.org/10.5109/4150512

出版情報 : Evergreen. 7 (4)，pp.593-601，2020-12. 九州大学グリーンテクノロジー研究教育センター バージョン：

権利関係： 


\title{
Biomass Production of Indonesian Indigenous Leptolyngbya Strain on NPK Fertilizer Medium and its Potential as a Source of Biofuel
}

\author{
Nining Betawati Prihantini ${ }^{1, *}$, Nurul Rakhmayanti ${ }^{1}$, Sri Handayani ${ }^{2}$, \\ Wellyzar Sjamsuridzal $^{1}$, Wisnu Wardhana ${ }^{1}$ and Nasruddin ${ }^{3}$ \\ ${ }^{1}$ Department of Biology, Faculty of Mathematics and Natural Sciences, Universitas Indonesia, Kampus UI Depok \\ 16424, Indonesia \\ ${ }^{2}$ Department of Chemistry, Faculty of Mathematics and Natural Sciences, Universitas Indonesia, Kampus UI \\ Depok 16424, Indonesia \\ ${ }^{3}$ Department of Mechanical Engineering, Faculty of Engineering, Universitas Indonesia, Kampus UI Depok \\ 16424, Indonesia
}

\begin{abstract}
*Author to whom correspondence should be addressed:
E-mail: nining.prihantini@gmail.com; nining@sci.ui.ac.id
\end{abstract}

(Received November 4, 2020; Revised December 9, 2020; accepted December 16, 2020).

\begin{abstract}
Leptolyngbya is one of the genera of Cyanobacteria (prokaryotic microalgae) which are often found in the hot spring area. These microalgae are known to have potential as a biofuels source. In order to utilize microalgae, it is necessary to make efforts to produce microalgae biomass in large quantities. Biomass production depends on many environmental factors, one of which is the medium. The use of appropriate media and cheaply be one option, since biomass must be produced in large scale. Therefore, research on variations in the concentration of NPK fertilizer medium against the growth of Leptolyngbya HS-16 compared to Bold Basal Medium (BBM) was carried out. NPK fertilizer medium (nitrogen/N, phosphorus/P and potassium/K) is an inexpensive microalgae growth medium. Leptolyngbya HS-16 or Leptolyngbia with strain code of HS-16 is a Leptolyngbia strain isolated from a habitat in the hot springs of Mount Pancar Crater in Indonesia. The purpose of the study was to determine the effect of NPK medium concentration on the biomass weight of Leptolyngbya HS-16. The medium used in the study was BBM as the control medium, and NPK media with various concentrations of $80 \mathrm{ppm}, 160 \mathrm{ppm}$, and $240 \mathrm{ppm}$ as the treatment medium. In addition, the study aimed to determine the appropriate concentration of NPK medium to produce high biomass weight, supported by high lipid content. The results showed that Leptolyngbya HS-16 grew better in NPK medium with a concentration of $80 \mathrm{ppm}$ compared to other concentrations. This can be seen from the results of the average biomass produced at peak time of $3.008 \mathrm{mg}^{-1} \mathrm{~L}^{-1}$ and the log length of the Leptolyngbya HS-16. The lipid content was produced in the $80 \mathrm{ppm}$ NPK medium was $45 \%$.
\end{abstract}

Keywords: Leptolyngbya; Cyanobacteria; Biomass weight; Lipid content; Biofuel

\section{Introduction and background}

Biomass is an organism's raw material that can be used for human benefit, one of which is a source of renewable energy in addition to other commonly used natural sources such as sunlight and wind ${ }^{1)}$. Biomass can be converted into energy or other useful chemical products, for example through the biorefinery process ${ }^{2}$. Biomass sources can be higher plants which are commonly used, for example oil palm ${ }^{3)}$. Apart from macroorganisms, biomass can also come from microorganisms (microorganisms). In contrast to the biomass from macroorganisms that can be directly used, biomass from microorganisms requires a technique to reproduce it before use. In the process of multiplying microorganisms, many things need to be considered, one of which is the composition of the medium. The right composition of the medium can make the growth of microorganisms fast and produce good biomass. Microalgae are an example of microorganisms that are often made of biomass for use.

Microalgae are unicellular organisms that can carry out carbon fixation ${ }^{4}$. Microalgae has the potential to be used as a source of biofuel production. This potential is supported by the ability of microalgae to produce biofuel 
raw materials, i.e. lipids ${ }^{5)}$. Microalgae also has several advantages compared to plants such as faster growth, being able to fix $\mathrm{CO}_{2}$ as a source of carbon, so it does not need sugar, and is genetically easily engineered ${ }^{6}$. Another advantage possessed by these organisms, which does not require a large area of land to multiply biomass ${ }^{7)}$. Microalgae consists of prokaryotic and eukaryotic organisms $^{4}$. One of the prokaryotic organisms that can potentially be used as a source of biofuel production is cyanobacteria $^{8)}$. The organism does not have organelles like those of eukaryotic organisms ${ }^{9}$.

Cyanobacteria cell walls are generally the same as Gram-negative bacterial cell walls ${ }^{10}$. The cell wall of gram-negative bacteria is composed of two layers, namely the outer and periplasmic membranes. The outer membrane consists of lipopolysaccharide (LPS) and peptidoglycan. Lipopolysaccharides (LPS) are composed of two types of polysaccharides, namely Opolysaccharide and core polysaccharide, proteins, and lipids A. Lipid A is a type of fatty acids that bind with amino acid groups to form glucosamine phosphate ${ }^{9)}$.

Cyanobacteria can be found in a variety of habitats, one of which is in waters ${ }^{11)}$. The organism can be found in hot spring waters. Cyanobacteria found in hot springs have the ability to adapt at high temperatures, causing cyanobacteria to be able to live at normal to high temperatures. This is due to the presence of heat shock proteins (HPSs) in the body's metabolism of cyanobacteria $^{12)}$. Some genus of cyanobacteria has been found in the hot springs of the Red Crater at Mount Pancar. Leptolyngbya is one of the cyanobacteria that has been found in the hot spring of Mount Pancar Red Crater ${ }^{13)}$.

Leptolyngbya is one of the genera of cyanobacteria that has unbranched filaments. The characteristics of the genus, which have a simple trichome shape and a trichome diameter of 0.5 to $3.5 \mu \mathrm{m}^{14)}$. Komarek (2014) classified Leptolyngbya into the Kingdom Eubacteria, Phylum Cyanobacteria, Class Cyanophyceae, Order Synechococales, Family Leptolyngbyaceae and Genus Leptolyngbya ${ }^{15)}$.

Leptolyngbya is thought to be able to be used for biofuel production, because Leptolyngbya can produce lipids ${ }^{16)}$. Beetul (2014) observed the production of lipids produced by several types of microalgae, one of which is Leptolyngbya $^{17)}$. In that study it was reported that Leptolyngbya produced quite large lipids compared to other microalgae groups, which amounted to $19.09 \%$ of the total biomass. Lipid production is supported by the provision of appropriate nutrients. Biomass of an organism can be said to be good if it is supported by high lipid and protein content. High lipid and protein content can be obtained by providing the right nutrients.

Based on the amount of needs of a nutrient organism is divided into two, i.e. macronutrients and micronutrients. Macronutrients are substances that are needed in large quantities to support growth, while micronutrients are substances that are needed in small amounts to support growth $^{18)}$. Some macronutrients that can support the propagation of biomass, i.e. nitrogen $(\mathrm{N})$, phosphorus $(\mathrm{P})$, and potassium $(K)^{19)}$. Nitrogen $(N)$ plays a role in the formation of chlorophyll. If nitrogen deficiency occurs, the formation of chlorophyll is disrupted, and chlorosis occurs. Phosphorus (P) plays a role in cell metabolic processes such as energy transfer, nucleic acid biosynthesis. Meanwhile, potassium (K) acts as an activator of enzymes that play a role in photosynthesis and respiration ${ }^{20)}$. These elements are used as the main elements in microalgae growth media, especially cyanobacteria $^{21)}$.

Bold Basal medium (BBM) is one of the growth media that is often used to grow microalgae ${ }^{22)}$. One of the microalgae that can be grown in BBM is Chlorella vulgaris. This microalga is a member of the Chlorophyta division. Wong (2017) reports that the highest lipid content of Chlorella vulgaris is grown in the BBM by $17.64 \%$ of the total biomass ${ }^{5}$. In addition, the BBM medium has been used to grow cyanobacteria. Prihantini (2015) grows cyanobacteria in the BBM medium ${ }^{13)}$. One of the cyanobacteria grown in the BBM medium is Leptolyngbya $^{13)}$. However, the lipid content of these organisms in the BBM medium is unknown.

$\mathrm{BBM}$ is a synthetic medium consisting of 16 types of chemicals. These chemicals have uneconomic prices, so that when used on a large-scale production costs are higher Therefore, research on the growth of cyanobacteria using a cheaper (economic) medium was carried out. This is done in order to produce cyanobacteria biomass that can produce lipids in large quantities, so that it has the potential to be used as biofuel with low production prices.

Apart from synthetic medium, the medium derived from waste can also be used for the growth of microalgae including cyanobacteria such as tofu production waste ${ }^{23)}$. This medium is more economical than synthetic medium. However, to study the effect of the elements contained in the waste is not easy. Therefore, in this study, the NPK fertilizer medium was used.

Research on growth medium at an economic price has been carried out. One of the growth media with economical price is using NPK commercial fertilizer ${ }^{24)}$. The medium has been used to grow Scenedesmus sp. and able to produce high lipids of $28.55 \%$ of the total biomass $^{25)}$. Comparison of NPK commercial fertilizers used, which is equal to 20:20:20. NPK growth medium with a ratio of 20:20:20 can be said to have a balanced nitrogen, phosphorus, and potassium content ${ }^{26)}$. Balanced nutrient content is expected to produce biomass with good protein and lipid production.

Providing the right nitrogen $(\mathrm{N})$, phosphorus $(\mathrm{P})$ and potassium (K) can produce Leptolyngbya HS-16 biomass. Growth medium used in the study are BBM as a control, and NPK 20:20:20 medium with variations in concentrations as a treatment medium.

The study aims to determine the effect of NPK medium concentration on the weight of Leptolyngbya HS-16 
biomass. In addition, the research aims to determine the administration of NPK media in the right concentration to produce high biomass weight, supported by high lipid content. The research hypothesis is that variations in the concentration of NPK medium can affect the weight of Leptolyngbya HS-16 biomass. Giving the right concentration of NPK fertilizer can produce high biomass weight which will also result in high lipid levels.

\section{Method and experimental setup}

\subsection{Microorganisms and Growth medium}

Microorganisms used in this study were isolates originating from Indonesia (indigenous species), namely Leptolyngbya HS-16 originating from the Red Crater of Mount Pancar hot spring, isolated in 2015 ${ }^{13)}$.

Growth medium is a medium that contains nutrients needed by microorganisms to be able to live. The medium used in the study, i.e. BBM medium as a control, and the NPK medium with several variations of concentration. Variations in concentration were given, consisting of 80, 160, and $240 \mathrm{ppm}$. The weight of N, P \& K content in the medium used is shown in Table 1 . Commercial fertilizer used is NPK 20:20:20 [Grow More]. Other chemicals used for lipid tests are methanol and chloroform.

Table 1. Weight of N, P \& K content in the medium

\begin{tabular}{ccrrr}
\hline $\begin{array}{c}\text { Element } \\
\mathbf{N}, \mathbf{P}, \mathbf{K}\end{array}$ & $\begin{array}{c}\text { BBM } \\
\mathbf{( m g )}\end{array}$ & \multicolumn{3}{c}{$\begin{array}{c}\text { NPK commercial fertilizer } \\
\mathbf{( m g )}\end{array}$} \\
\hline $\mathrm{N}$ & 41,17 & 16 & 32 & 48 \\
\hline $\mathrm{P}$ & 53,48 & 16 & 32 & 48 \\
\hline $\mathrm{K}$ & 300,285 & 16 & 32 & 48 \\
\hline
\end{tabular}

\subsection{Research design}

The treatment given to Leptolyngbya HS-16 was grown in various concentrations of NPK medium. The concentration variations given consisted of 80,160, and 240 ppm. Growth in the NPK medium was compared with the control medium (BBM). The study was conducted for 25 days of observation with six replications each treatment. The number of repetitions is obtained from the Frederer calculation formula, is (t-1) (n-1) $\geq 15$, which $t$ is the number of treatments, while $\mathrm{n}$ is the number of repetitions.

\subsection{Manufacture of BBM and NPK medium}

Manufacture of the medium of BBM is done by mixing chemicals dissolved in distilled water. The BBM formula is based on NIES 200721). The BBM is wet sterilized using an autoclave at $121{ }^{\circ} \mathrm{C}$ for 15 minutes. Meanwhile, NPK medium comes from NPK commercial fertilizer [Grow More] in a ratio of 20:20:2027). Preparation of NPK medium is done by dissolving NPK 20:20:20 commercial fertilizer in $1000 \mathrm{~mL}$ distilled water. NPK fertilizer is dissolved depending on the concentration to be made. A concentration of $80 \mathrm{ppm}$ is produced by dissolving $80 \mathrm{mg}$ of NPK commercial fertilizer into $1000 \mathrm{~mL}^{28)}$. The same ways are used to obtain concentrations of $160 \mathrm{ppm}$ and 240 ppm. NPK commercial fertilizers that have been added are then homogenized by stirring using a magnetic stirrer stirring rod. Homogeneity of acidity $(\mathrm{pH})$ medium is measured with universal $\mathrm{pH}$ indicator paper. The homogenized NPK medium and $\mathrm{pH}$ measured are put into a medium bottle. The medium bottle is covered with a bottle cap and wrapped in aluminum foil. The NPK medium was then sterilized wet using an autoclave at 121 ${ }^{\circ} \mathrm{C}$ for 15 minutes. Table 2 show the composition of NPK [Grow More] commercial fertilizer ${ }^{27}$.

Table 2. The composition of NPK commercial fertilizers

\begin{tabular}{lc}
\hline \multicolumn{1}{c}{ Composition } & Percentage (\%) \\
\hline Total nitrogen & 20 \\
\hline- Ammoniacal & 3.9 \\
\hline- Nitrate & 5.7 \\
\hline - Urea & 10.4 \\
Phosphate $\left(\mathrm{P}_{2} \mathrm{O}_{5}\right)$ & 20 \\
\hline Potassium $\left(\mathrm{K}_{2} \mathrm{O}\right)$ & 20 \\
\hline $\mathrm{Ca}$ & 0.05 \\
\hline $\mathrm{Mg}(\mathrm{MgO})$ & 0.10 \\
\hline $\mathrm{S}\left(\mathrm{combination}^{2}\right)$ & 0.20 \\
\hline $\mathrm{B}\left(\mathrm{B}_{2} \mathrm{O}_{3}\right)$ & 0.02 \\
\hline $\mathrm{Cu}(\mathrm{CuO})$ & 0.05 \\
\hline $\mathrm{Fe}\left(\mathrm{Fe}_{2} \mathrm{O}_{3}\right)$ & 0.10 \\
\hline $\mathrm{Mn}(\mathrm{MnO})$ & 0.05 \\
\hline $\mathrm{Molybdenum}\left(\mathrm{MoO}_{3}\right)$ & 0.0005 \\
\hline $\mathrm{Zn}(\mathrm{ZnO})$ & 0.05 \\
\hline Inert Ingredient & 39 \\
\hline
\end{tabular}

\subsection{Propagation of biomass of Leptolyngbya HS-16}

Biomass propagation was done by inoculation of Leptolyngbya HS-16 cultures into a $50 \mathrm{~mL}$ Erlenmeyer flask with $40 \mathrm{~mL}$ of BBM. The biomass was stored in an incubation cabinet of $35^{\circ} \mathrm{C}$. A large amount of biomass is then transferred to the $250 \mathrm{~mL}$ Erlenmeyer flask ${ }^{13)}$.

\subsection{Preparation of stock, working, and starter culture of Leptolyngbya HS-16}

There are three (3) types of culture that used in this study, i.e. stock, working, and starter culture. Stock culture is a culture that will be stored in an incubation cabinet of $35^{\circ} \mathrm{C}$. Working culture is a culture that is used to be used as a starter culture. Meanwhile, starter culture is a culture that is used as a test culture. Preparation of stock, working, and starter culture are carried out by mixing $180 \mathrm{~mL}$ of $\mathrm{BBM}$ and $20 \mathrm{~mL}$ of Leptolyngbya culture, and put it into $250 \mathrm{~mL}$ Erlenmeyer flask. The cultures are grown in incubation cabinets at $35^{\circ} \mathrm{C}^{13}$.

\subsection{Inoculation of test cultures}


The test culture comes from the starter culture. Preparation of test culture was carried out by put $60 \mathrm{mg}$ of each Leptolyngbya HS-16 into the prepared BBM and NPK medium. A total of $60 \mathrm{mg}$ of culture was obtained by taking $2 \mathrm{~mL}$ of culture and centrifuging for 10 minutes at $10,000 \mathrm{rpm}$. Supernatant is removed, the pellets obtained are weighed to reach $60 \mathrm{mg}$. The culture that was weighed was put into an Erlenmeyer flask containing $200 \mathrm{~mL}$ medium. The treatment on each medium was repeated six times. Total test cultures obtained were 24 test cultures.

\subsection{Laying arrangement of test cultures in incubation} cabinet

Test cultures were placed in an incubation cabinet at 35 ${ }^{\circ} \mathrm{C}$. The distance between the test cultures is based on the measurement of light intensity using a luxmeter. Optimum light intensity in the growth of Leptolyngbya, which is 2500-3000 lux ${ }^{29}$. Laying scheme in the closet incubation test cultures can be seen in Fig. 1.

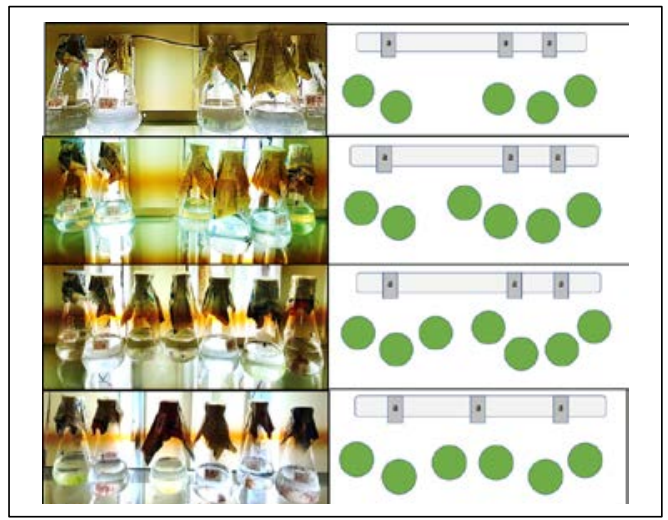

Fig.1: Schematic placement of the test culture in a $35^{\circ} \mathrm{C}$ incubation cabinet: Note: a. Light

\subsection{Macroscopic and microscopic observations}

Macroscopic observations were carried out for each data collection, i.e. at observations $t_{0}, t_{1}, t_{2}, t_{3}, t_{4}, t_{6}, t_{7}, t_{11}$, $t_{14}, t_{18}, t_{21}$ and $t_{25}$. These observations were made by comparing the culture color with Faber Castell's standard colors. Leptolyngbya cell measurements are carried out using a camera microscope by looking at the measuring lines printed on the screen. Measurement and microscopic observations of Leptolyngbya HS-16 were carried out at observations as mentioned above.

\subsection{Measurement of biomass weight of Leptolyngbya}

\section{HS-16}

Weight measurements of Leptolyngbya HS-16 biomass were performed 11 times on observations of $t_{0}, t_{1}, t_{2}, t_{3}, t_{4}$, $\mathrm{t}_{6}, \mathrm{t}_{7}, \mathrm{t}_{11}, \mathrm{t}_{14}, \mathrm{t}_{18}, \mathrm{t}_{21}$ and $\mathrm{t}_{25}$. Measurement of biomass begins with weighing the $2 \mathrm{~mL}$ Eppendorf micro tube. Biomass was taken aseptically with a micropipette of $2 \mathrm{~mL}$. The biomass was put into a sterile $2 \mathrm{~mL}$ Eppendorf micro tube which had measured its empty weight. A 2 mL Eppendorf micro tube containing Leptolyngbya biomass was centrifuged for 10 minutes at 10,000 rpm. The supernatant was removed with a sterile Pasteur pipette and discarded. The pellets in the $2 \mathrm{~mL}$ Eppendorf micro tube were dried in an oven at $40{ }^{\circ} \mathrm{C}$ for about 6 hours. Dried pellets are weighed with analytical scales. The weight of biomass can be obtained from the difference between the Eppendorf tube containing a dry pellet with an empty Eppendorf tube.

\subsection{Measurement of lipid content of Leptolyngbya}

\section{HS-16}

Lipid content measurement of Leptolyngbya HS-16 was carried out at $\mathrm{t}_{0}$ and $\mathrm{t}_{25}$. Measurement of lipid content was carried out by the Bligh \& Dyer method ${ }^{30)}$. The measurement begins with the preparation of biomass of Leptolyngbya HS-16. The total biomass produced at each repetition of the strain is centrifuged. Pellets that have been obtained as much as $1 / 10$ of the total volume, which is equal to $3 \mathrm{~mL}$, is transferred to the mortar. The pellet is mashed by adding a mixture of $1: 2$ chloroform and methanol as much as $3 \mathrm{~mL}$. The mixture was put into a $100 \mathrm{~mL}$ Erlenmeyer flask. The mixture was sonicated with a sonicator for 30 minutes. This serves to help the process of Leptolyngbya cell wall lysis. Samples that have been sonicated, added a mixture of distilled water and chloroform 1:1 as much as $2.5 \mathrm{~mL}$ each. The sample was sonicated again for 30 minutes (It has been reprocessed from Addana ${ }^{31)}$.

The sonicated sample was transferred into a $15 \mathrm{~mL}$ centrifugation tube, then centrifuged for 15 minutes at $4000 \mathrm{rpm}$. Supernatant and pellet are separated by vacuum pump, i.e. the mixture is poured into a vacuum funnel that has been given filter paper, so that the pellets are left on the filter paper. The supernatant formed is transferred to the extraction flask and allowed to stand for several minutes. This will form impurities and a mixture of chloroform with separate lipids. The chloroform mixture with lipids was transferred into a petri dish by opening the extraction pumpkin faucet slowly. Lipid solution and chloroform that are already in the petri dish, then dried with a hot plate in the fume hood. This is done so that chloroform evaporates. The petri dish is re-dried in an oven at $105{ }^{\circ} \mathrm{C}$ for 2 hours, so that the chloroform completely evaporates. Lipid weight is obtained from the difference between the weight of an empty petri dish and the weight of a petri dish with dry lipids ${ }^{31}$. Lipid levels of Leptolyngbya can be calculated using the following formula: \% Total Lipid $=($ DLP $(g)) /($ DCW $(g)) \times 100 \%$; Note: DLP: lipid dry weight (g); DCW: weight of sample biomass $(\mathrm{g})^{32)}$.

\subsection{Measurement of environmental conditions}

Measurement of environmental conditions is very 
important to support research. Environmental conditions such as temperature and light intensity were measured during the study.

\subsection{Data Compilation, Processing and Analysis}

The observation generates qualitative and quantitative data in the form. Qualitative data in the form and shape of cells from Leptolyngbya HS-16. Quantitative data are in the form of $\mathrm{pH}$, cell size, biomass weight $\left(\mathrm{mg} . \mathrm{L}^{-1}\right)$, and lipids content (\%). Data on biomass weight will be displayed in tabular and graphical form, lipid content in tabular form, and cell shape and color will be displayed in photographic form.

Data analysis begins with the Kolmogorov-Smirnov normality test. Distribution of data generated is not normally distributed, then the data is tested with the Kruskal-Wallis test ${ }^{33)}$. The data was tested to find out whether or not there were differences in the variation of NPK commercial fertilizer concentrations on the biomass average of Leptolyngbya HS-16.

\section{Results and Discussion}

\subsection{Macroscopic and Microscopic Observations of}

\section{Leptolyngbya HS-16 Culture}

Macroscopic observation of Leptolyngbya HS-16 was carried out by observing the color of the culture of Leptolyngbya HS-16 formed, which is emerald green. The color of the Leptolyngbya HS-16 culture is likened to the Faber Castell color standard. The macroscopic appearance of the Leptolyngbya HS-16 starter culture in Erlenmeyer is shown in Fig. 2. The starter culture, which was used as a 36-day-old test culture, was incubated at $35^{\circ} \mathrm{C}$ in the BBM medium.

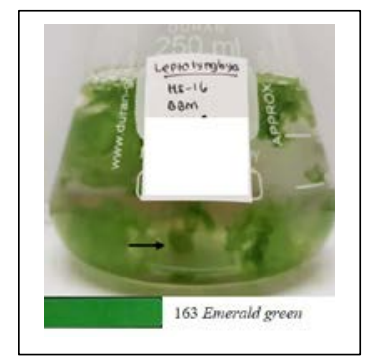

Fig.2: Macroscopic appearance of starter of Leptolyngbya HS16 in BBM medium: Arrow $(\rightarrow$ ) Biomass of Leptolyngbya HS16 in $250 \mathrm{~mL}$ Erlenmeyer flask

Macroscopic culture observations of Leptolyngbya HS16 were carried out on the day of observation to (t) $t_{0}, t_{1}$, $t_{2}, t_{3}, t_{4}, t_{6}, t_{7}, t_{11}, t_{14}, t_{18}, t_{21}$ and $t_{25}$. Macroscopic appearance of Leptolyngbya HS-16 in the medium of BBM, 80 ppm NPK, 160 ppm NPK and 240 ppm NPK on observations from day 0 to day 6 did not experience discoloration. The color change on the $6^{\text {th }}$ day observation occurred only on 240 ppm NPK medium, which is yellowish green (apple green). Macroscopic appearance of Leptolyngbya HS-16 on the $7^{\text {th }}$ day and $11^{\text {th }}$ day also did not experience a change in color in the medium of BBM, NPK of 80 ppm, 160 ppm and 240 ppm from previous observations. The color change occurred on the $14^{\text {th }}$ day in 80 ppm NPK, 160 ppm NPK and 240 ppm NPK. Macroscopic appearance on days 18, 21, and 25 in each medium did not change color from previous observations. The difference from the macroscopic appearance of Leptolyngbya HS-16 in each medium on the day of observation to ( $t)_{0}, t_{1}, t_{2}, t_{3}, t_{4}, t_{6}, t_{7}, t_{11}, t_{14}, t_{18}, t_{21}$ and $t_{25}$. is shown in Fig.3.

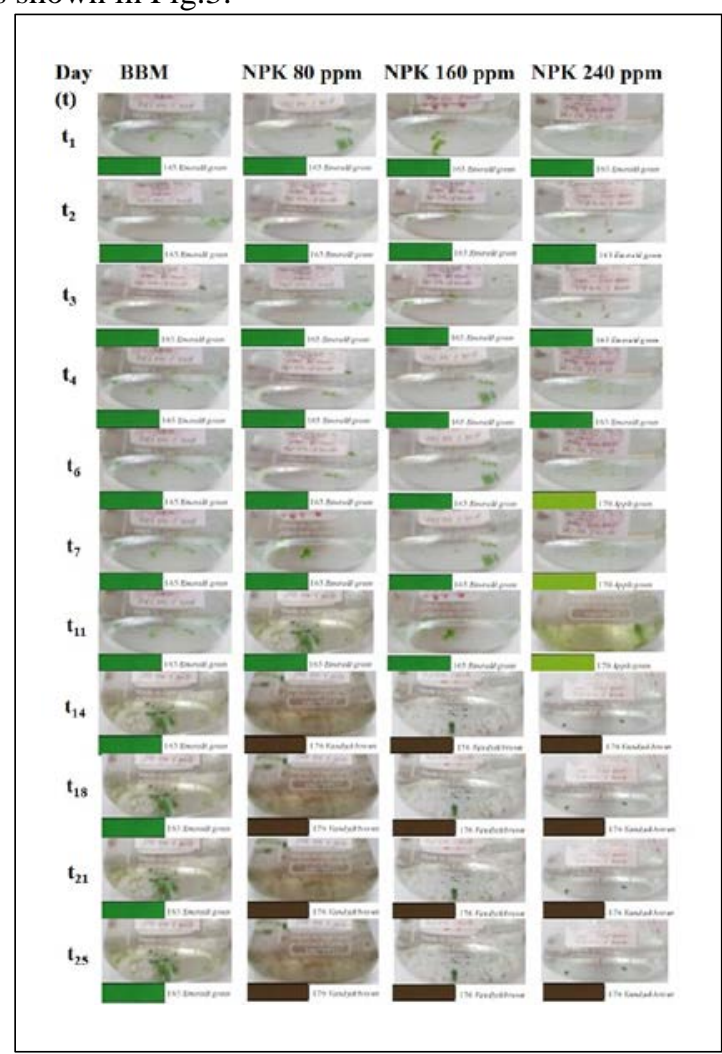

Fig.3: Macroscopic appearance of Leptolyngbya HS-16 at to to $\mathrm{t}_{25}$

Macroscopic appearance of Leptolyngbya HS-16 on the $6^{\text {th }}$ day in 240 ppm NPK medium changed color. Changes in color of Leptolyngbya HS-16 in the 240 ppm NPK medium are most likely to occur, because the nitrogen content in the medium is higher than in the NPK medium concentrations of $80 \mathrm{ppm}$ and 160 ppm. High nitrogen content in the medium can cause the disruption of photosynthetic pigment formation, due to the deactivation process of photosynthetic pigment activity ${ }^{24)}$. The process of deactivation of photosynthetic pigments is caused by available nitrogen sources. Different sources of nitrogen can also cause deactivation of photosynthetic pigments.

Nitrogen sources are available in NPK medium, i.e. in the form of ammonium, nitrate, and urea. The percentage of the largest nitrogen source content in the NPK medium is found in urea, which is $10.4 \%$ of the $20 \%$ total nitrogen content ${ }^{27)}$. When urea is dissolved in water, it becomes 
ammonium hydroxide $\left(\mathrm{NH}_{4} \mathrm{OH}\right)$. Ammonium uptake in cells is regulated by ammonium transporters (Amt). Amt compounds play a role in regulating the nitrogen content in cells. Ammonium content in cells is too high will inhibit the activity of Amt, so cells cannot control the uptake of nitrogen into cells ${ }^{34)}$. Ammonium content in high cells will also disrupt the hydrolysis reaction. The hydrolysis reaction is the reaction of the breakdown of water into $\mathrm{H}$ + and $\mathrm{OH}^{-}$ions. The hydrolysis reaction will be disrupted because ammonium will bind to OEC in the PSII structure, resulting in the photodamage process. The photodamage process results in the loss of pigment in cells ${ }^{34)}$.

Discoloration of Leptolyngbya HS-16 in NPK medium is likely due to reduced nitrogen content in the medium. Nitrogen deficiency in growth media will disrupt the process of the formation of pigment components of the accessories, so it will change the color of cyanobacteria. This is due to the role of nitrogen to stabilize the bonding of colored chemical compounds (chromophore) in phycobilin. When nitrogen is reduced, the chemical bonds in the chromophore become unstable causing the cell color to change $\mathrm{e}^{35}$.

Microscopic observations were made by measuring the width of the Leptolyngbya HS-16 cell diameter. Leptolyngbya HS-16 cell measurements were performed on each observation day. The cell size of Leptolyngbya's normal trichome diameter is 0.5 to $3.5 \mu \mathrm{m}^{14)}$. The results of cell diameter measurements of Leptolyngbya HS-16 from day 1 to day 25 vary in each medium. Size of cell diameter of Leptolyngbya HS-16 on days 1 to 25 in the $\mathrm{BBM}$ medium ranged from 2.78 to $3.4 \mu \mathrm{m}$; $80 \mathrm{ppm}$ NPK medium ranging from 2.67 to $5.6 \mu \mathrm{m} ; 160 \mathrm{ppm}$ NPK medium ranging from 2.98 to $6.5 \mu \mathrm{m} ; 240 \mathrm{ppm}$ NPK medium ranging from 3.12 to $6.2 \mu \mathrm{m}$. Comparison of Leptolyngbya HS-16 cell diameter sizes can be seen in Fig. 4.

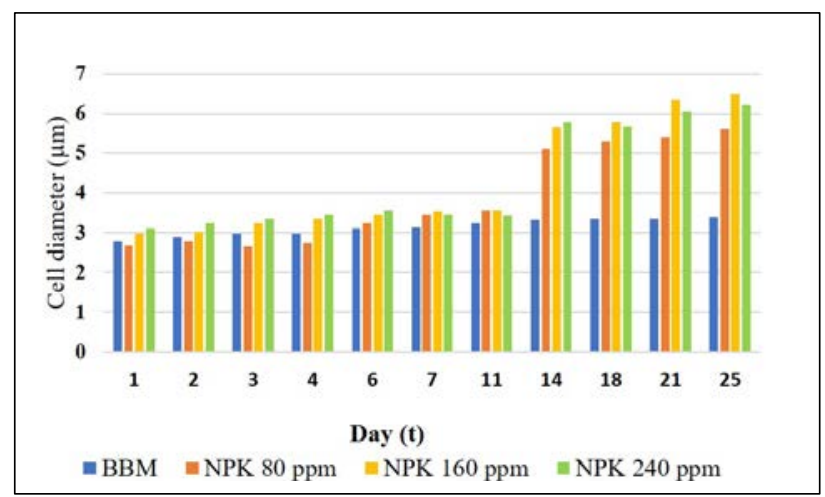

Fig.4: Comparison of the size of the cell diameter Leptolyngbya HS-16

Changes in Leptolyngbya HS-16 cell size to be larger in NPK of 80, 160 and 240 ppm medium are likely to occur, because the nitrogen sources that exist in the NPK medium have all been used. Nitrogen sources that are not available in the growth medium cause Leptolyngbya HS16 to experience nitrogen starvation. Nitrogen starvation causes the process of degradation of phycobilisome pigments so that the process of photosynthesis is disrupted. One of the products produced in the process of photosynthesis, i.e. carbon atoms that function in cell wall synthesis. The process of photosynthesis is disrupted, and carbon synthesis will be reduced, so that the components of the cell wall will be disrupted. If the components of the cell wall are reduced, the cell wall becomes unstable. The instability of the cell wall causes the cell size to become $\operatorname{larger}^{36)}$.

\subsection{Biomass Weight and Growth Curve of}

\section{Leptolyngbya HS-16}

Data collection of Leptolyngbya HS-16 biomass weight was carried out on observations $\mathrm{t}_{0}, \mathrm{t}_{1}, \mathrm{t}_{2}, \mathrm{t}_{3}, \mathrm{t}_{4}, \mathrm{t}_{6}, \mathrm{t}_{7}, \mathrm{t}_{11}, \mathrm{t}_{14}$, $t_{18}, t_{21}$ and $t_{25}$. The number of Leptolyngbya HS-16 starter cultures entered into the test culture was $60 \mathrm{mg}$ in $200 \mathrm{~mL}$ medium. This was done so that each treatment received a uniform number of Leptolyngbya HS-16 cultures.

The results of the average weight of biomass Leptolyngbya HS-16 with repetitions 6 times in each medium contained in Table 3. Based on the average biomass weight table, on days 1 to 3 there was an increase, but on the $4^{\text {th }}$ day there was a decrease in each medium. Increase and decrease of Leptolyngbya HS-16 biomass still occur until the $11^{\text {th }}$ day on each treatment medium. Increases and decreases in the growth curve occur, because Leptolyngbya HS-16 is still undergoing an adaptation phase to environmental conditions that is only known as the lag phase. The lag phase occurs when microorganisms are inoculated into a new medium ${ }^{9}$. The length of the lag phase of a microorganism depends on the age of the starter culture used in the inoculum. The age of the starter culture used was 36 days $^{37)}$. Growth curve can be seen in Fig.5. based on the table that has been made.

The results of the average weight of biomass Leptolyngbya HS-16 at day 14 increased in the treatment medium, except in the $160 \mathrm{ppm}$ NPK medium. The increase continued until the $18^{\text {th }}$ day, except in the 240 ppm NPK medium. A very significant increase occurred on the $18^{\text {th }}$ day in $80 \mathrm{ppm}$ NPK medium. If the weight of Leptolyngbya HS-16 biomass in the control medium is compared to $80 \mathrm{ppm}$ NPK, the weight of the biomass produced in $80 \mathrm{ppm}$ NPK medium is higher. The results showed that Leptolyngbya HS-16 was able to grow well in 80 ppm NPK medium compared to control medium. In addition, to achieve the highest biomass of Leptolyngbya HS-16 in 80 ppm NPK medium only requires 18 days. This shows that the log phase length of Leptolyngbya HS-16 on 80 ppm NPK medium is faster than the control medium. The average weight of Leptolyngbya HS-16 biomass on days 21 to 25 decreased in each treatment medium, especially on $80 \mathrm{ppm}$ NPK medium. The average weight of biomass in the $160 \mathrm{ppm}$ NPK medium did not decrease significantly, and the 240 ppm NPK medium did not increase or decrease. 
Table 3. Average biomass weight of Leptolyngbya HS-16

\begin{tabular}{|c|c|c|c|c|}
\hline \multirow[b]{2}{*}{$\begin{array}{c}t \\
\text { (Day) }\end{array}$} & \multicolumn{4}{|c|}{ Weight (mg/mL) } \\
\hline & $\begin{array}{c}\text { Average of } \\
\text { BBM }\end{array}$ & $\begin{array}{c}\text { Average of } \\
\text { NPK } \\
80 \mathrm{ppm} \\
\end{array}$ & $\begin{array}{c}\text { Average of } \\
\text { NPK } \\
160 \mathrm{ppm} \\
\end{array}$ & $\begin{array}{c}\text { Average of } \\
\text { NPK } \\
240 \mathrm{ppm} \\
\end{array}$ \\
\hline 0 & $0.300 \pm 0.000$ & $0.300 \pm 0.000$ & $0.300 \pm 0.000$ & $0.300 \pm 0.000$ \\
\hline 1 & $0.125 \pm 0.076$ & $0.083 \pm 0.040$ & $0.050 \pm 0.000$ & $0.158 \pm 0.220$ \\
\hline 2 & $0.158 \pm 0.111$ & $0.108 \pm 0.073$ & $0.050 \pm 0.000$ & $0.100 \pm 0.077$ \\
\hline 3 & $0.325 \pm 0.377$ & $0.341 \pm 0.146$ & $0.133 \pm 0.112$ & $0.158 \pm 0.120$ \\
\hline 4 & $0.175 \pm 0.150$ & $0.100 \pm 0.063$ & $0.158 \pm 0.080$ & $0.108 \pm 0.066$ \\
\hline 6 & $0.183 \pm 0.116$ & $0.216 \pm 0.263$ & $0.242 \pm 0.058$ & $0.133 \pm 0.075$ \\
\hline 7 & $0.083 \pm 0.025$ & $0.141 \pm 0.091$ & $0.125 \pm 0.059$ & $0.050 \pm 0.000$ \\
\hline 11 & $0.191 \pm 0.146$ & $0.166 \pm 0.075$ & $0.208 \pm 0.159$ & $0.100 \pm 0.063$ \\
\hline 14 & $0.333 \pm 0.140$ & $0.441 \pm 0.304$ & $0.108 \pm 0.049$ & $0.166 \pm 0.087$ \\
\hline 18 & $1.080 \pm 1.393$ & $3.008 \pm 2.740$ & $0.150 \pm 0.077$ & $0.158 \pm 0.265$ \\
\hline 21 & $1.290 \pm 2.870$ & $2.033 \pm 2.996$ & $0.908 \pm 2.000$ & $0.100 \pm 0.054$ \\
\hline 25 & $0.860 \pm 1.850$ & $0.100 \pm 0.044$ & $0.892 \pm 2.061$ & $0.100 \pm 0.044$ \\
\hline
\end{tabular}

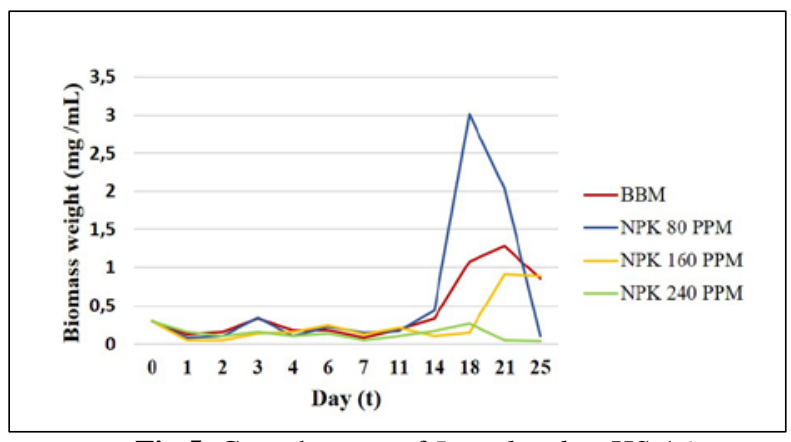

Fig.5: Growth curve of Leptolyngbya HS-16

Increases and decreases in biomass weight of Leptolyngbya HS-16 are likely to occur still adapting to new nutrient conditions, so that they are still in the adaptation phase $\mathrm{e}^{9}$. Nutrient concentration in the medium can also affect the length of the adaptation phase. This can occur due to the higher concentration of commercial medium given, the length of the adaptation phase that is experienced. Ammar (2015) examined the growth of Chlorella in various concentrations of NPK medium ${ }^{24)}$. Based on these results, it is known that the higher the concentration given, the longer the adaptation phase of Chlorella to the concentration of the medium. The length of the lag phase is due to the higher concentration of nitrogen given which causes the deactivation of pigment production which plays a role in photosynthesis and the process of photosynthesis is disrupted ${ }^{24)}$. The process of photosynthesis is disrupted it will inhibit the production of biomass. In the process of inhibiting the production of biomass as occurs in changes in cell size.

The mean weight of Leptolyngbya HS-16 biomass in the BBM, NPK of $80 \mathrm{ppm}, 160 \mathrm{ppm}$ and $240 \mathrm{ppm}$ medium were statistically tested to see whether there was an influence or not the concentration of the medium on the weight of the biomass. Normality test is performed to determine whether the data is normally distributed or not. The data normality test uses the Kolmogorov-Smirnov test. Based on the results of normality tests on each medium, it can be said that the average weight of Leptolyngbya HS-16 biomass on the BBM medium, 80 ppm, 160 ppm and 240 ppm medium have an abnormal distribution. Therefore, statistical tests are performed with non-parametric statistical tests.

The non-parametric statistical test used is the Kruskal Wallis test. Based on the results of the Kruskal Wallis test, variations in the concentration of NPK medium have an influence on the weight of the Leptolyngbya HS-16 biomass. It can be seen that there are significant differences in the average weight of biomass to variations in NPK concentrations. Post Kruskal Wallis further tests were conducted after knowing that there were significant differences in mean weight of biomass against variations in the NPK medium concentration. The post-KruskalWallis test was carried out to determine the groups that had significant differences in biomass weight against variations in the NPK medium concentration. The results of the post-Kruskal Wallis test, namely all groups had significant differences in mean weight of biomass to variations in the concentration of NPK medium. Statistical test results support the observations and measurements that have been made.

\subsection{Lipid content of Leptolyngbya HS-16}

Measurement of lipid content was done as supporting data of the biomass weight of Leptolyngbya HS-16. Lipid content measurement of Leptolyngbya HS-16 was carried out on the starter and on the $25^{\text {th }}$ day. The starter culture used is 36 days old and grown in BBM medium. Lipid content in starter cultures, which is as much as $56 \%$ of the total weight of biomass.

The lipid content of Leptolyngbya HS-16 in four different media is varied. Based on the results of the lipid content of Leptolyngbya HS-16 on the $25^{\text {th }}$ day in the BBM was $48 \%$ with a biomass weight of $11.4 \mathrm{mg}$ and a lipid weight of $5.5 \mathrm{mg}$; medium of 80 ppm NPK by $45 \%$ with biomass weight of $7.9 \mathrm{mg}$ and lipid weight of $3.6 \mathrm{mg}$; medium of 160 ppm NPK by 54\% with biomass weight $8.5 \mathrm{mg}$ and lipid weight $4.6 \mathrm{mg}$; and medium of $240 \mathrm{ppm}$ NPK by $58 \%$ with biomass weight of $6 \mathrm{mg}$ and lipid weight of $3.5 \mathrm{mg}$. The results of measurements of lipid content at $\mathrm{t}_{25}$ in each medium can be seen in Table 4 .

Table 4. Leptolyngbya HS-16 Lipid content on the $25^{\text {th }}$ day

\begin{tabular}{lccc}
\hline Medium & $\begin{array}{c}\text { weight } \\
\text { biomass } \\
\text { (mg) }\end{array}$ & $\begin{array}{c}\text { Lipid } \\
\text { weight } \\
\text { (mg) }\end{array}$ & $\begin{array}{c}\text { Lipid } \\
\text { content } \\
\text { (\%) }\end{array}$ \\
\hline BBM & 11.4 & 5.5 & $48 \%$ \\
\hline NPK 80 ppm & 7.9 & 3.6 & $45 \%$ \\
\hline NPK 160 ppm & 8.5 & 4.6 & $54 \%$ \\
\hline NPK 240 ppm & 6 & 3.5 & $58 \%$ \\
\hline
\end{tabular}

The results showed that the lipid content of Leptolyngbya HS-16 in four different mediums varied. Based on Table 4, the highest lipid content was found in Leptolyngbya HS-16 in 240 ppm NPK medium, which is 
$58 \%$ of the total biomass. When compared with the lipid content in the starter, the Leptolyngbya HS-16 in 240 ppm NPK medium has a higher lipid content. The highest lipid content in the 240 ppm NPK medium is likely to occur, because cells in Leptolyngbya HS-16 experience stress on the environment, thus producing the highest lipids compared to other media. High lipid content appears when conditions in the environment do not support cyanobacteria for life, so that the organism produces lipids as a form of self-defense. High lipid production occurs so that the cell wall becomes thicker, so that cyanobacteria are able to survive in unsupportive environmental conditions. One of the environmental conditions that causes Leptolyngbya HS-16 produces high lipids, which is dependent on the concentration of available nutrients. The concentration of nutrients available in the $240 \mathrm{ppm}$ NPK medium can cause Leptolyngbya HS-16 cells to experience environmental stress.

The lipid content of Leptolyngbya HS-16 in the BBM medium, NPK of $160 \mathrm{ppm}$ and $80 \mathrm{ppm}$ are less than the lipid content in the starter. The high lipid content may also be influenced by the age of the culture used. The starter culture used was 36 days old, while the test culture measured was 25 days old.

\section{Conclusions}

The conclusions that can be drawn from the results of the study are as follows. Variation in NPK fertilizer concentration affects the weight of Leptolyngbya HS-16 biomass. Eighty (80) ppm NPK medium concentration is the right concentration for the growth of Leptolyngbya HS-16. This can be seen from the weight of the biomass produced on the $18^{\text {th }}$ day and the log phase length compared to the control medium. Lipid content that produced in 80 ppm NPK medium was $45 \%$.

\section{Acknowledgements}

This work was funded by Hibah Penelitian Dasar Unggulan Perguruan Tinggi (PDUPT), Ministry of Research and High Education (Kemenristek Dikti), Fiscal Year of 2019 to Nining Betawati Prihantini, grant no. NKB-1605/UN2.R3.1/HKP.05.00/2019.

\section{References}

1) T. Hanada. Modifying the Feed-in Tariff System in Japan: An Environmental Perspective. EVERGREEN Joint Journal of Novel Carbon Resource Sciences \& Green Asia Strategy 5 (2). 5458 (2016)

2) Z. F. Zahara. Economic Assessment of the Sugarcane-based Bio-refinery in Indonesia. EVERGREEN Joint Journal of Novel Carbon Resource Sciences \& Green Asia Strategy 5 (2). 6777 (2018).
3) A. Kuncoro, \& W. W. Purwanto. Analysis of EnergyWater Nexus Palm Oil Biodiesel Production in Riau Using Life Cycle Assessment and Water Footprint Methods. EVERGREEN Joint Journal of Novel Carbon Resource Sciences \& Green Asia Strategy 7 (1) 104-110 (2020).

4) HuLab 2012. Green Fuel: Microalge - The next biofuel producer. http://hulab.ucf.edu/microalgae/ introduction (accessed July 16, 2018).

5) Y. K Wong, Y. H. Ho, K. C. Ho, H. M. Leung, \& K. K. L. Yung. Growth medium screening for Chlorella vulgaris growth and lipid production. Journal of Aquaculture \& Marine Biology. 6(1): 1-10. (2017).

6) N. E. Nozzi, J. W. K. Oliver, S. Atsumi. Cyanobacteria as a Platform for Biofuel Production. Frontiers in Bioengineering and Biotechnology 1 (7). 1-6. (2013)

7) K. Ullah, M. Ahmad, Sofia, V. K. Sharma, P. Lu, A. Harvey, M. Zafar, S. Sultana, \& C. N. Anyanwu. Algal biomass as a global source of transport fuels: Overview and development perspectives. Progress in Natural Science Materials International. 24: 329339, (2014).

8) C. Van Den Hoek, D. G. Mann, \& H. M. Jahns. Algae: an introduction to phycology. Cambridge university press. USA, p. 637. (2002).

9) M. Madigan, J. Martino, K. Bender, D. Buckley, D. Stahl. Brock Biology of Microorganisms. $14^{\text {th }}$ ed. Pearson Education. United States of America, p. 1030. (2015).

10) R. E. Lee. Phycology. Cambridge university press. USA, p. 660. (1989).

11) H. C. Bold \& M. J. Wynne. Introduction to the algae. Prentice-Hall Inc. USA, p.722. (1978).

12) Z. Zhaoqi. High temperature adaptation of freshwater cyanobacterium. Journal of Lake Science. 6(4): 356-363. (1994).

13) N. B. Prihantini. Polyphasic Taxonomy of Culturable Cyanobacteria Isolated from Hot Springs in West Java, Indonesia. Dissertation Department of Biology, Faculty of Mathematics and Natural Sciences, Depok, p. 115. (2015).

14) J. Komarek. Phenotype diversity of the cyanobacterial genus Leptolyngbya in the maritime Antarctic. Polish polar research. 3:211-231. (2007).

15) J. Komarek, J. Kastovsky, J. Mares \& J. R. Johansesn. Taxonomic classification of cyanoprokaryotes (cyanobacterial genera) 2014, using a polyphasic approach. Preslia. 86: 295-335. (2014).

16) L. Giddings \& D. J. Newman. Bioactive compounds from terrestrial extremophiles. Springer, USA, p. 77. (2015).

17) K. Beetul, S. B. Sadally, N. Taleb-Hossenkhan, R. Bhagooli, \& D. Puchooa. An investigation of biodiesel production from microalgae found in Mauritian waters. Biofuel Research Journal. 2: 5864. (2014). 
18) Y. Xu. Molybdenum and Iron interactions as micronutrients for growth of a freshwater cyanobacterium, Microcystis aeruginosa. Graduate Thesis for Master of Science, Biology University of Western Ontario, Ontario, p. 97. (2015).

19) A. Mangaiyarkarasi, D. R. Geetha, \& M. Naveena. Optimization of fertilizer based media for the cultivation of Scenedesmus species. Internasional Journal of Pharma and Bio Sciences. 8(3): 615-621 (2017).

20) G. Markou, D. Vandamme, \& K. Muylaert. Microalgal and cyanobacterial cultivation: The supply of nutrients. Water research. 65: 186-202. (2014).

21) NIES. NIES-Collection List of Strains $6^{\text {th }}$ edition Microalgae and Protozoa. National Institute of Environtmental Studies. Tsukuba, p. v +159. (2007).

22) R. A. Andersen. Algal Culturing Techniques. Elsevier Academic Press. California, p. 589 (2005).

23) B. T. Sabarudin, S. Kartohardjono. The Combination of Coagulation-Flocculation and Membrane Processes to Minimize Pollution of Tofu Wastewater. EVERGREEN Joint Journal of Novel Carbon Resource Sciences \& Green Asia Strategy 7 (1). 5660 (2020)

24) S. H. Ammar. Cultivation of Microalgae Chlorella vulgaris in Airlift photobioreactor for Biomass Production using commercial NPK nutrients. AlKhawarizmi Engineering Journal. 12(1): 90-99. (2015).

25) M. Nayak, M. Thirunavoukkarasu, \& R. C. Mohanty. Cultivation of freshwater microalga Scenedesmus sp. using a low-cost inorganic fertilizer for enhanced biomass and lipid yield. Applied Microbiology, Molecular and Cellular Biosciences Research Foundation. 6: 7-13. (2016).

26) L. Lingga. Anthurium. Penerbit PT Gramedia Pustaka Utama. Jakarta, p. 79. (2007).

27) Grow More. 2013. Water soluble fertilizer. http://www.growmore.com/products/type/watersoluble-fertilizer.html\#, (accessed March 8, 2018).

28) S.R. Ardiansyah, A. M. Orlando, A.Rahman, N. B. Prihantini, Nasruddin. Tubular Photobioreactor: A Preliminary Experiment Using Synechococcus sp. (Cyanobacteria) Cultivated in NPK Media for Biomass Production as Biofuel Feedstock. EVERGREEN Joint Journal of Novel Carbon Resource Sciences \& Green Asia Strategy 6 (2).157161 (2019).

29) V. Verma, and M. B. Bhattacharjee. Growth and nitrate metabolism in the thermohalophilic cyanobacterium Leptolyngbya. Journal of Algal Biomass Utilization. 6(2): 68-75. (2015).

30) E. G. Bligh, and W. J. Dyer. A rapid method of total lipid extraction and purification. Canadian Journal of Biochemistry and Physiology. 37: 911-917. (1959).
31) Addana, F. Pengaruh penggunaan ekstrak kompos sebagai medium kultur terhadap pertumbuhan produksi lipid Nannochloropsis sp. Skripsi Sarjana S1 Departemen Biologi, FMIPA, Universitas Indonesia, Depok, p. 96. (2014).

32) Y. Li, M. Horsman, B. Wang, and N. Wu. Effect of nitrogen sources on cell growth and lipid accumulation of green algae Neochloris oleoabundanss. Applied Microbiol Biotechnology. 81: 629-636. (2008).

33) S. Siregar. Metode penelitian kuantitatif: dilengkapi dengan perbandingan perhitungan manual dan SPSS. Kencana, Jakarta, p. 537. (2013).

34) M. Drath, N. Kloft, A. Batschauer, K. Marin, J. Novak, and K. Forchhammer. Ammonia Triggers Photodamage of Photosystem II in the Cyanobacterium Synechocystis sp. Strain PCC 6803 ${ }^{1[\mathrm{OA}]}$. Plant Physiology. 147: 206-215. (2008).

35) A. R. Grossman. Chromatic adaptation and the events involved in phycobilisome biosynthesis. Plant, Cell and Environment. 13(1990): 651-666. (1990).

36) S. K. Saha, L. Uma, and G. Subramanian. Nitrogen stress induced changes in the marine cyanobacterium Oscillatoria willei BDU 130511. FEMS Microbiology Ecology. 45: 263-272. (2003).

37) S. Hogg. Essential Microbiology. John Wiley and Sons Ltd, USA, p. 463. (2005). 